\title{
Humic Acid and Trihalomethane Breakdown with Potential By- Product Formations for Atmospheric Air Plasma Water treatment
}

\author{
Chaitanya Sarangapani \\ Technological University Dublin, chaitanyakrishna.sarangapani@tudublin.ie \\ Peng Lu \\ Technological University Dublin \\ Patrice Behan \\ Patrice Behan, patrice.behan@tudublin.ie
}

See next page for additional authors

Follow this and additional works at: https://arrow.tudublin.ie/schfsehart

Part of the Food Science Commons

\section{Recommended Citation}

NOT PUBLISHED YET doi:10.1016/j.jiec.2017.10.042

This Article is brought to you for free and open access by the School of Food Science and Environmental Health at ARROW@TU Dublin. It has been accepted for inclusion in Articles by an authorized administrator of ARROW@TU Dublin. For more information, please contact arrow.admin@tudublin.ie, aisling.coyne@tudublin.ie, gerard.connolly@tudublin.ie.

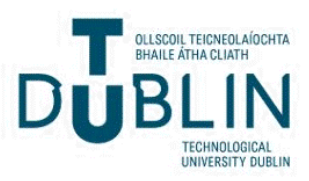


Authors

Chaitanya Sarangapani, Peng Lu, Patrice Behan, Paula Bourke, and Patrick Cullen

This article is available at ARROW@TU Dublin: https://arrow.tudublin.ie/schfsehart/276 


\title{
Humic acid and trihalomethane breakdown with potential by-product formations for atmospheric air plasma water treatment
}

\author{
Chaitanya Sarangapani ${ }^{\mathrm{a}}$, Peng Lu ${ }^{\mathrm{a}}$, Patrice Behan ${ }^{\mathrm{b}}$, Paula Bourke ${ }^{\mathrm{a}}$, P.J. Cullen ${ }^{\mathrm{a}, \mathrm{c}, \mathrm{d}, *}$ \\ a BioPlasma Research Group, School of Food Science and Environmental Health, Dublin Institute of Technology, Dublin 1, Ireland \\ b School of Chemical and Pharmaceutical Sciences, Dublin Institute of Technology, Kevin St., Dublin 8, Ireland \\ ' School of Chemical Engineering, University of New South Wales, Sydney, Australia \\ d Department of Chemical and Environmental Engineering, University of Nottingham, Nottingham NG7 2RD, United Kingdom
}

A R T I C L E I N F O

\section{Article history:}

Received 22 August 2017

Received in revised form 12 October 2017

Accepted 21 October 2017

Available online $\mathrm{xxx}$

\section{Keywords:}

Atmospheric air plasma

Humic acid

Trihalomethane

Degradation

Disinfection by-products (DBPs)

\begin{abstract}
A B S T R A C T
In this study an atmospheric air plasma reactor was studied for the degradation of HA and THMs in water. Plasma treatment showed significant breakdown efficacies for HA and THMs. At an applied voltage of $80 \mathrm{kV}$ about $93 \%$ of $\mathrm{HA}$ and $>70 \%$ of THMs were degraded after $15 \mathrm{~min}$ and $30 \mathrm{~min}$ treatment time respectively, with the degradation following a first order kinetic model. Plasma induced reactive species including nitrates and $\mathrm{H}_{2} \mathrm{O}_{2}$ were quantified in the treated water. The results of FTIR analysis revealed that the molecular structure of HA was altered by the plasma treatment, with a decrease in aromaticity observed.
\end{abstract}

(C) 2017 The Korean Society of Industrial and Engineering Chemistry. Published by Elsevier B.V. All rights reserved.

\section{Introduction}

Over the past century chlorine has been widely used as an oxidant in water and wastewater treatment. Chlorine's efficacy is demonstrated for microbial inactivation of a wide variety of pathogens along with oxidation of various chemical contaminants. However, the potential formation of disinfection by-products (DBPs), such as trihalomethane, is a concern [1]. DBPs, including trihalomethanes, can be formed as a consequence of the reaction of chlorine with natural organic matter (NOM) present in both surface and ground water [2]. NOM comprises of two fractions; humic substances (HS), which are composed of humic acids, fulvic acids, and non-humic substances (non-HS), which include carbohydrates, lipids, and amino acids [3]. Furthermore, humic acids constitute a major fraction of NOM, of which the soluble portion (aromatic compounds) of humic substances may react with chlorine to form trihalomethanes [4]. It has been reported that these THMs are carcinogens [5]. Epidemiologic studies in humans suggest a weak association with bladder, rectal and colon cancer [6,7] along with reproductive and developmental effects $[8,9]$.

\footnotetext{
* Corresponding author at: BioPlasma Research Group, School of Food Science and Environmental Health, Dublin Institute of Technology, Dublin 1, Ireland.

E-mail address: pjcullen@dit.ie (P.J. Cullen).
}

Due to these health concerns, many jurisdictions specify maximum allowable concentrations. The United States Environmental Protection Agency [10] specifies maximum levels for trihalomethanes (THMs) and haloacetic acids (HAAs) of 80 and $60 \mu \mathrm{g} / \mathrm{L}$, respectively [11]. European Union regulations limit THMs to $100 \mu \mathrm{g} / \mathrm{L}$. However, many national reports find frequent occurrence of THM exceedance [12]. It is important to limit THMs and THMs causing substances (humic acids) in water.

Several approaches such as nanofiltration, ultrafiltration, reverse osmosis coagulation [13], activated carbon adsorption [14], Fenton treatment [15], nano- $\mathrm{TiO}_{2}$ photocatalysis [16], membrane filtration [17], biological treatment [18], and ozonation [19] have been employed to remove humic substances and THM's. Biological processes, including the use of bio-filters may lead to the accumulation of suspended solids and release of bacteria [20]. Separation technologies such as biofilms and membrane filtration may be limited due to fouling [21]. Ozone's efficacy for humic substance breakdown in water has been demonstrated, however the process may result in the formation of brominated by-products [22]. In addition, the use of such advanced oxidation processes (AOP) which are capable of oxidizing some of the NOM present in raw water sources require an additional step for mineralization increasing the operational cost. Therefore, there is a need to develop novel approaches to remove humic substances and THMs in energy efficient manner. 
Recently, atmospheric plasma technology has emerged as an advanced oxidation process for waste water treatments, potentially offering effective removal rates and environmental compatibility [23]. The use of atmospheric air as the inducer gas facilitates a potentially environmentally friendly and economically feasible approach. Atmospheric air plasma has been reported to be efficient in the breakdown of dyes [24], pesticides [25,26], aflatoxins [27] and for inactivation of pathogenic bacteria [28]. It is known that dielectric barrier discharge (DBD) plasma initiates several physical processes (UV light, shock waves) and chemical processes $\left(\mathrm{O}^{\circ}, \mathrm{O}_{3}\right.$, $\mathrm{H}_{2} \mathrm{O}_{2}$ ) [29], processes which may directly or indirectly act on humic substances. However, limited studies investigate the potential of atmospheric plasma for the breakdown of THMs [30] and HA [31,32]. It is also important to understand the potential for the formation of DBPs after plasma treatment of humic substances to demonstrate the technology's suitability for water treatment.

The objective of this work is to study the efficacy of atmospheric air plasma for the degradation of HA and THMs. In addition, the potential for DBP formation post plasma treatment is also studied.

\section{Materials and methods}

\section{Materials}

Humic acid (HA) and a trihalomethanes (THM) mix containing; chloroform $\left(\mathrm{CHCL}_{3}\right)$, bromodichloromethane (BDCM), dibromochloromethane (DBCM), bromoform (BF) were all analytical grade and purchased from Sigma-Aldrich, Ireland. The THM mix was dissolved in methanol to obtain a standard stock solution with a concentration of $100 \mathrm{mg} / \mathrm{L}$. The prepared stock solution was diluted to obtain a minimum concentration of $20 \mathrm{mg} / \mathrm{L}$. Samples of $100 \mathrm{mg} /$ $\mathrm{L}$ and $200 \mathrm{mg} / \mathrm{L}$ of HA solution were prepared in deionized water and filtered through $0.45 \mu \mathrm{m}$ Millipore membranes.

\section{Atmospheric air plasma treatment}

A prototype high voltage atmospheric air plasma reactor, based on a dielectric barrier discharge (DBD) design was used in this study and described previously by Sarangapani et al. [26]. Briefly, plasma is generated between two circular aluminium plate electrodes (outer diameter $=158 \mathrm{~mm}$ ) using two thick acrylic dielectric layers (Fig. 1). The applied voltage to the electrode was provided by a step-up transformer (Phenix Technologies, Inc.,
MD, USA) which has the input of $230 \mathrm{~V}, 50 \mathrm{~Hz}$ from the mains supply. Experiments for THM and HA were conducted separately. For each experiment $20 \mathrm{~mL}$ of THM and HA solution was added to petri dishes and subjected to different doses of direct plasma treatment. The atmospheric air conditions at the time of treatment was $40 \pm 1 \%$ relative humidity $(\mathrm{RH})$ and $16 \pm 2{ }^{\circ} \mathrm{C}$, as measured using a humidity-temperature probe connected to a data logger (Testo 176T2, Testo Ltd., UK). Plasma treatment was performed at variable discharge voltage levels $(60-80 \mathrm{kV})$ and treatment durations (0-30 min). After processing, the sealed reactors containing the sample were stored at room temperature of $16-18^{\circ} \mathrm{C}$ for $24 \mathrm{~h}$ to facilitate diffusion of the reactive species and reaction with the spiked compounds. No attempt was made to optimise the diffusion process, as the objective to this work was to study the effects of plasma treatment under controlled conditions. Electrical characterisation of the discharge was performed using an Agilent InfiniVision 2000 X-Series Oscilloscope (Agilent Technologies Inc., USA). The voltage across the electrode was recorded using a high voltage North Star PVM-6 probe together with a 10:1 voltage divider. The current waveform was measured using a current transformer probe (Bergoz CT-E1.0S).

\section{Analysis}

THMs analysis was carried out using GC-MS, (Varian 3800 GC, JVA Analytical Ltd., Ireland) with a 2200 Varian ion trap MS. SPME extractions for all plasma treated samples were performed using carboxen-polydimethylsiloxane (CAR-PDMS) fibres. The fibres were conditioned at $300^{\circ} \mathrm{C}$ for $1 \mathrm{~h}$ before use, and blank desorption's were carried out periodically. Each sample $(20 \mathrm{~mL})$ was transferred into a vial $(40 \mathrm{~mL})$. The incubation and extraction temperature was $35^{\circ} \mathrm{C}$, and the samples were equilibrated for $10 \mathrm{~min}$ before extraction. The magnetic stirring speed was $1000 \mathrm{rpm}$. The fibre, attached to a syringe, was placed in the sample headspace for $15 \mathrm{~min}$, drawn back into the needle, and transferred without delay $(<5 \mathrm{~s})$ into the GC injection port, where it was desorbed for $3 \mathrm{~min}$ at $280^{\circ} \mathrm{C}$. All analyses were performed in triplicate. The oven temperature program was $40^{\circ} \mathrm{C}$ for $4 \mathrm{~min}$, increased at $5^{\circ} \mathrm{C} \mathrm{min}^{-1}$ to $80^{\circ} \mathrm{C}$, then increased at $20^{\circ} \mathrm{C} \mathrm{min}^{-1}$ to $180^{\circ} \mathrm{C}$, with a split less injection mode employed. The analytical column was a Zebron ZB-5MS column and the carrier gas was helium, at $1 \mathrm{mLmin}^{-1}$. The mass detector was operated in the electron impact (EI) mode at $70 \mathrm{eV}$ and electron multiplier voltage

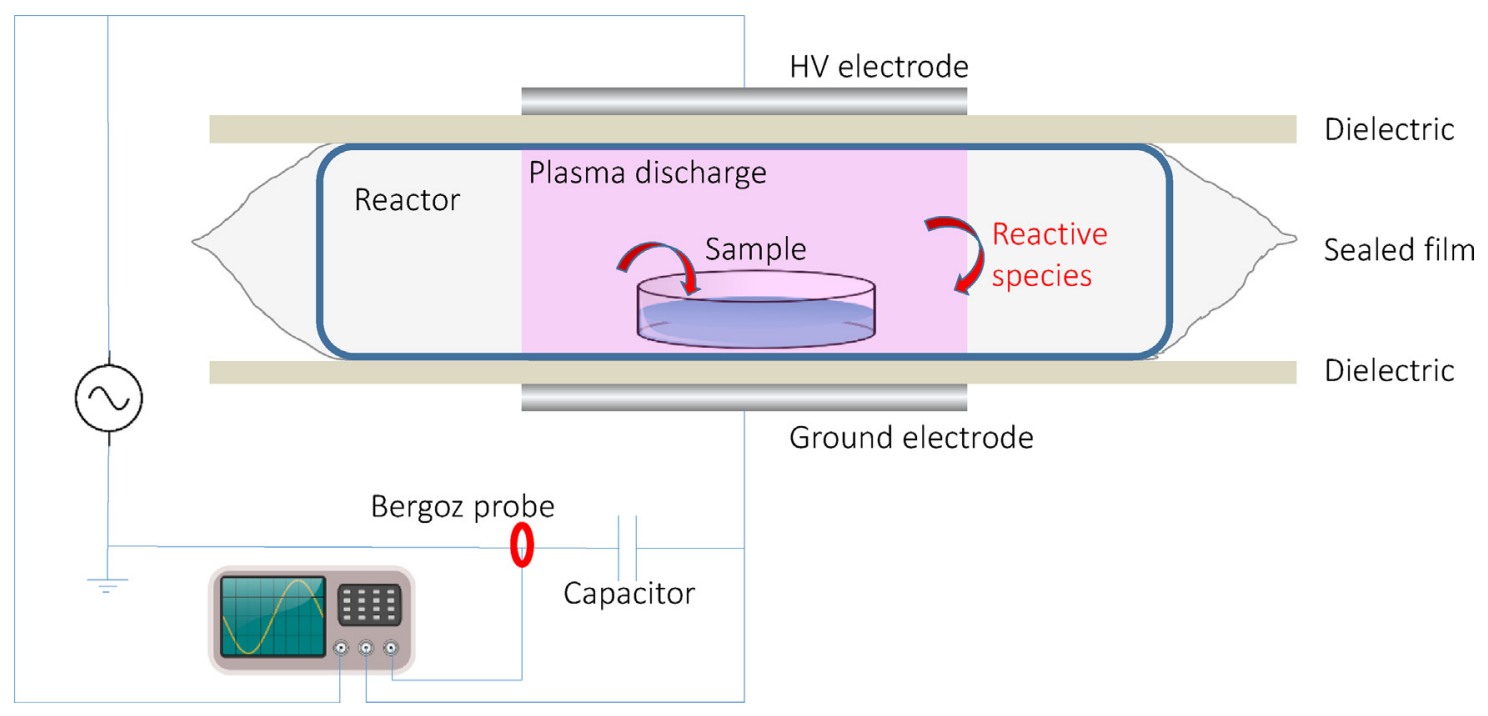

Fig. 1. Schematic of the experimental setup. 


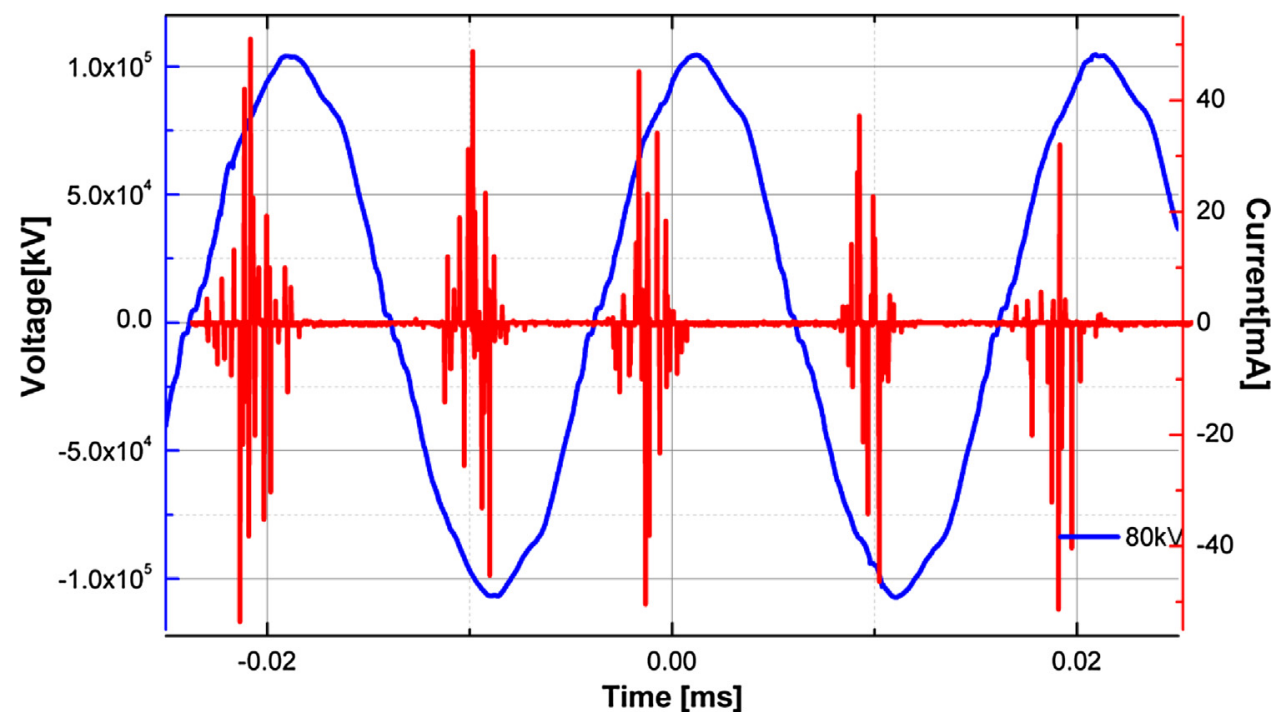

Fig. 2. Representative $I-V$ waveforms of the discharge in packages at $80 \mathrm{kV}$ applied voltage.

of $1.25 \mathrm{kV}$. The mass spectrum acquisition range was $m / z 35-400$, and analytes were identified from their fragmentation patterns using the NIST Mass Spectral Search Program 05 [33]

HA concentrations were measured using a spectrophotometer (Shimadzu UV 1800, Shimadzu Scientific Instruments) calibrated at $254 \mathrm{~nm}$. The removal efficiency was measured using following equation.

$\eta=\frac{C_{0}-C}{C_{0}} \times 100$

where $\eta$ is removal efficiency of each HA/THM, ' $C$ ' is the concentration of $\mathrm{HA} / \mathrm{THM}$ at time ' $\mathrm{t}$ ' and ' $\mathrm{C}_{0}$ ' is the initial concentration of HA/THM. Plasma degradation of THM or HA in general followed first order kinetics as described in the following equation

$C=C_{0} \exp (-k t)$

where ' $k$ ' the degradation is rate constant $\left(\mathrm{min}^{-1}\right)$ of the reaction and ' $t$ ' is the treatment time ( $\mathrm{min})$.

Energy yield was calculated according to the procedure of Jiang et al. [34].

Energy yield $=\frac{\operatorname{COV} \eta(\%)}{100 P t}$

where ' $C_{0}$ ' is initial concentration of HA/THM, ' $V$ ' is the total volume of solution, ' $P$ ' is the input power and ' $t$ ' is the treatment time

The IR spectra were recorded in absorbance mode at $4 \mathrm{~cm}^{-1}$ resolution, using a fourier transform infrared spectrometer (Nicolet iS-5, Thermo Fisher Scientific Inc.,) equipped with an attenuated total reflectance (ATR) over the frequency range $4000-400 \mathrm{~cm}^{-1}$. The sample measurements were replicated for all individual samples of each treatment class. Analyses were carried out at room temperature of $25^{\circ} \mathrm{C}$. The background was collected prior to measurement of each sample. The $\mathrm{pH}$ of all samples was measured after $24 \mathrm{~h}$ storage using a calibrated glass electrode ORION pH meter (model 420A, Thermo Fisher Scientific Inc.).

Nitrate concentrations were determined photometrically by 2,6-dimethyl phenol (DMP) using a Spectroquant nitrate assay kit (Merck 1.09713, Darmstadt, Germany) and calculated using a NaNO3 standard curve. Hydrogen peroxide concentration was determined according to the procedure of Bohem et al. [35].

\section{Results and discussion}

\section{HA degradation kinetic study}

The typical current and voltage waveforms found for the discharge at different voltages are shown in Fig. 2. A stable nonthermal discharge was seen at a large gap of $23 \mathrm{~mm}$. The applied voltage was observed to be sinusoidal and the total current in the dielectric barrier discharge consists of filamentary streamers, which may trigger photo ionization [36]. The dielectric material plays a key role in the operation by limiting the charge and preventing arcing [37,38], which is particularly important for large discharge gaps and high voltages.

The degradation efficiencies for humic acid at different voltages are presented in Fig. 3. It is clear that the removal efficiency increases with applied voltage and treatment time. The final removal efficiencies after $15 \mathrm{~min}$ of treatment were found to be $72 \%, 82 \%, 93 \%$ at $60 \mathrm{kV}, 70 \mathrm{kV}$ and $80 \mathrm{kV}$, respectively for HA for an initial concentration of $100 \mathrm{mg} / \mathrm{L}$. The change in removal efficiency with treatment time and applied voltage, is attributed to the greater quantities of reactive species generated [23,26]. Higher voltages beyond $80 \mathrm{kV}$ could lead to further improvements in the treatment efficacies and reductions in treatment time. Humic acid degradation by atmospheric cold plasma can be described by a first-order kinetic model as shown in Fig. 3. As it can be observed from Table 1 that similar to the removal efficiencies, the rate constant increased from 0.08608 to $0.15509 \mathrm{~min}^{-1}$ for applied voltages of $60 \mathrm{kV}$ to $80 \mathrm{kV}$. Similar results have been reported by Gao et al. [39] for the degradation of $17 \beta$-estradiol in water by DBD. Panorel et al. [32] also reported similar increases in the reaction rates for pulsed corona treatment of aqueous humic acid.

The effect of the initial concentration of humic acid solution on the degradation efficiency is presented in Fig. 3(b). It can be observed that the removal efficiency abruptly decreased from 93\% to $86 \%$ with increases in concentration from $100 \mathrm{mg} / \mathrm{L}$ to $200 \mathrm{mg} / \mathrm{L}$ at $80 \mathrm{kV}$ for $15 \mathrm{~min}$ of treatment time. A significant decrease $(p<0.05)$ in removal efficiency with increases in concentration is due to the fact that at a fixed applied voltage, the active species produced in plasma discharge were maintained at specific concentration levels [39]. Therefore, longer treatment times should be given to diffuse activated species into the solution with high concentration for greater removal efficiencies [40]. It is also 

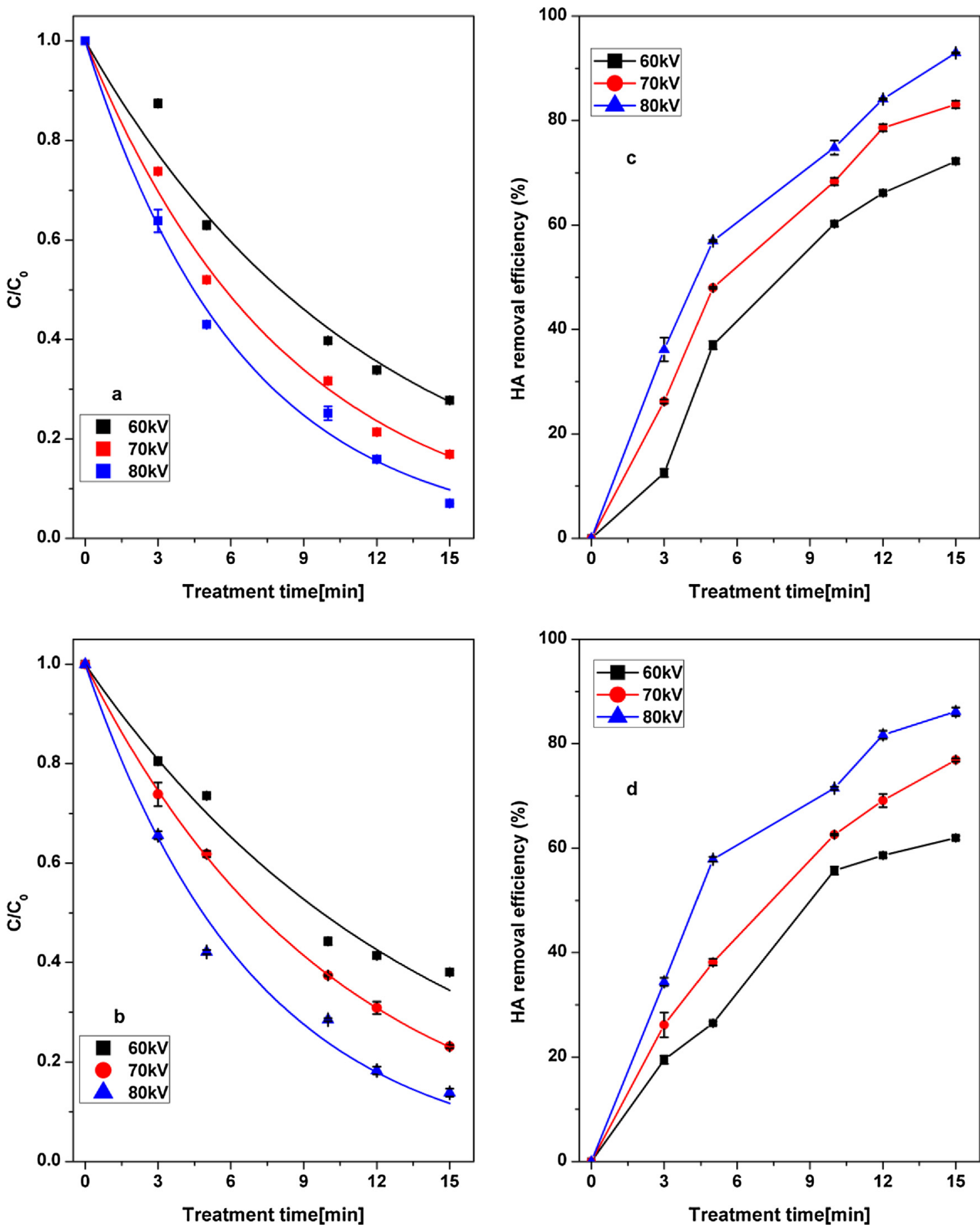

Fig. 3. Degradation kinetics of HA removal at initial concentration of (a) $100 \mathrm{mg} / \mathrm{L}$ and (b) $200 \mathrm{mg} / \mathrm{L}$ where (c) and (d) show corresponding removal efficiencies.

observed that the rate constant decreased from $0.15509 \mathrm{~min}^{-1}$ to $0.14314 \mathrm{~min}^{-1}$ with an increase in concentration of humic acid at $80 \mathrm{kV}$ for $15 \mathrm{~min}$ of plasma treatment. Similar results were reported for a DBD plasma treatment of crystal violet by Reddy and Subrahmanyam [41]. The energy yield values for the different voltages applied are presented in Fig. 4. The energy yield was decreased from $618 \times 10^{-6}$ to $459 \times 10^{-6} \mathrm{~g} / \mathrm{kW}$ h with an increase in voltage from $60 \mathrm{kV}$ to $70 \mathrm{kV}$. Fluctuations in energy yield can be related to the average energy of reactive species which are increasing with the enhancement of the treatment time. It was also observed that the energy yield doubled as the concentration of HA solution increased from 100 to $200 \mathrm{mg} / \mathrm{L}$ for applied voltages. Therefore, more energy is required to degrade the humic acid molecule at high concentrations with greater competition between humic acid molecules and active species [42]. Similar results have been demonstrated in previously published papers $[43,44]$. Photo electro catalysis of HA achieved an overall removal of $95 \%$ with $90-210$ min of treatment with energy yield values of $0.17-1.6 \mathrm{~g} / \mathrm{kW}$ h [45]. Similarly, $\mathrm{TiO}_{2}$ photo catalysis treatment of HA resulted in large amounts of disinfection by-products with slightly higher energy yield values $(0.12-0.75 \mathrm{~g} / \mathrm{kW} \mathrm{h})$ compared to the present study. Comparing with previous studies on humic acid 
Table 1

Model parameters for the first-order kinetic degradation of HA and THMs using atmospheric air plasma at various conditions.

\begin{tabular}{|c|c|c|c|}
\hline Process parameter & Value & Rate constant $k\left(\min ^{-1}\right)$ & $\mathrm{R}^{2}(\operatorname{Adj})$ \\
\hline \multicolumn{4}{|l|}{ Humic acid } \\
\hline \multirow[t]{3}{*}{$100 \mathrm{mg} / \mathrm{L}$} & 60 & $0.08608 \pm 0.00584$ & 0.97 \\
\hline & 70 & $0.12014 \pm 0.00429$ & 0.99 \\
\hline & 80 & $0.15509 \pm 0.00593$ & 0.99 \\
\hline \multirow[t]{3}{*}{$200 \mathrm{mg} / \mathrm{L}$} & 60 & $0.07109 \pm 0.00324$ & 0.98 \\
\hline & 70 & $0.09796 \pm 0.09796$ & 0.99 \\
\hline & 80 & $0.14314 \pm 0.00788$ & 0.98 \\
\hline \multirow[t]{3}{*}{ Radical scavenger } & 0 & $0.1177 \pm 0.00872$ & 0.97 \\
\hline & $4 \mathrm{mmol} / \mathrm{L}$ & $0.05238 \pm 0.00347$ & 0.96 \\
\hline & $6 \mathrm{mmol} / \mathrm{L}$ & $0.04145 \pm 0.002$ & 0.97 \\
\hline \multirow[t]{4}{*}{$\mathrm{pH}$} & 10.5 & $0.06837 \pm 0.00263$ & 0.98 \\
\hline & 8.5 & $0.10067 \pm 0.00883$ & 0.96 \\
\hline & 6.5 & $0.12448 \pm 0.0104$ & 0.97 \\
\hline & 2.5 & $0.03611 \pm 0.00168$ & 0.97 \\
\hline \multicolumn{4}{|l|}{ Trihalomethane } \\
\hline \multirow[t]{4}{*}{$10 \mathrm{mg} / \mathrm{L}$} & $\mathrm{CHCL}_{3}$ & $0.07054 \pm 0.0071$ & 0.95 \\
\hline & BDCM & $0.06705 \pm 0.0057$ & 0.96 \\
\hline & $\mathrm{DBCM}$ & $0.0484 \pm 0.00591$ & 0.92 \\
\hline & $\mathrm{BF}$ & $0.05424 \pm 0.0035$ & 0.96 \\
\hline \multirow[t]{4}{*}{$20 \mathrm{mg} / \mathrm{L}$} & $\mathrm{CHCL}_{3}$ & $0.06143 \pm 0.00592$ & 0.95 \\
\hline & BDCM & $0.0538 \pm 0.00352$ & 0.97 \\
\hline & DBCM & $0.03783 \pm 0.00403$ & 0.92 \\
\hline & $\mathrm{BF}$ & $0.04565 \pm 0.00261$ & 0.96 \\
\hline
\end{tabular}

degradation using AOP procesess our design was found to have slightly lower energy yield which may be due to the high initial concentration of the solution.

Thus, plasma treatment can be an efficient technique for the removal of humic acid at comparably short treatment times. The mechanism of humic acid degradation by plasma occurs through electrophilic attack of plasma active species such as ozone on electron rich sites. The major source of electron rich moieties are unsaturated carbon structures for instance the aromatic and olefinic groups. Functional groups of humic acids such as hydroxyls $(-\mathrm{OH})$ and amines $\left(-\mathrm{NH}_{2}\right)$ can enhance the reactivity of adjacent carbon bonds due to their electron donating capacity. On the other hand, functional carboxylic groups $(-\mathrm{COOH})$ may decrease the reactivity to adjacent carbon groups due to their electron withdrawing capacity $[46,47]$. It was observed that plasma treatment of humic acid resulted in decolourization, potentially due to the loss of aromaticity by decyclization of the humic acid macromolecule [48]. Another decolorization mechanism is attributed to the formation of pseudo-quinoic groups, formed by the electrophillic reaction of ozone with the phenolic groups of humic acid. Further increases in treatment doses results in breakdown of the aromatic cycle which results in the generation of carboxylic groups. Extended treatment results in the formation of byproducts such as aldehydes and carboxylic acids. Therefore, plasma treatment can affect the initial carbon structure and also the functionality of humic acids.

It is known that the initial pH of the solution is an important parameter governing the degradation process. The effect of $\mathrm{pH}$ on the removal efficiency was investigated for acidic, neutral, and alkaline solutions at a HA solution concentration of $100 \mathrm{mg} / \mathrm{L}$ and an applied voltage of $80 \mathrm{kV}$. As shown in Fig. 5(a) and (b), the removal efficiencies achieved were $67 \%, 82 \%, 90 \%$, and $38 \%$ for $\mathrm{pH}$ values of $10.5,8.5,6.5$ and 2.5 , respectively. A maximum removal efficiency of $90 \%$ was achieved at $\mathrm{pH} 6.5$, with relatively low efficiencies of $38 \%$ obtained for the acidic environment of $\mathrm{pH} 2.5$ after 15 min of plasma treatment. It is known that atmospheric air plasma generates numerous active species including; $\mathrm{O}_{3}, \mathrm{OH}, \mathrm{H}_{2} \mathrm{O}_{2}$ by electron disassociation of oxygen and water molecules, followed by subsequent chemical reactions [49]. In addition, indirect degradation is also possible through UV light and shock waves [50,51]. For details on the generation of $\mathrm{O}_{3},{ }^{\bullet} \mathrm{OH}, \mathrm{H}_{2} \mathrm{O}_{2}$ and other plasma species the reader is directed to previous publications [52,53]. The atmospheric plasma oxidation mechanism of chemical contaminants may occur via direct and indirect (forming $\mathrm{OH})$ mechanisms. However, both reactions can occur simultaneously and ozone may react with unsaturated functional groups present in organic molecules. The first stage of oxidation occurs through ozone molecular reactions, which proceed via electrophillic attack on the azo chromophoric groups and double bonds of $-\mathrm{C}=\mathrm{C}-$ connecting aromatic groups [54]. Rapid oxidation might occur due to cleavage of the conjugated bonds of humic acid molecules [55]. Direct reactions are predominant in acidic environments and are efficient processes for compounds with functional groups, aromatic systems (phenolics) or double bonds. The $\mathrm{pH}$ values of plasma treated humic acid solutions were reduced significantly $(\mathrm{pH} \leq 2.5)$ after $15 \mathrm{~min}$ of plasma treatment irrespective of the initial $\mathrm{pH}$. This is attributed to the formation and accumulation of strong acids such as nitric acids, nitrous acid and other carboxylic acids [53]. This resulted in a decrease in the
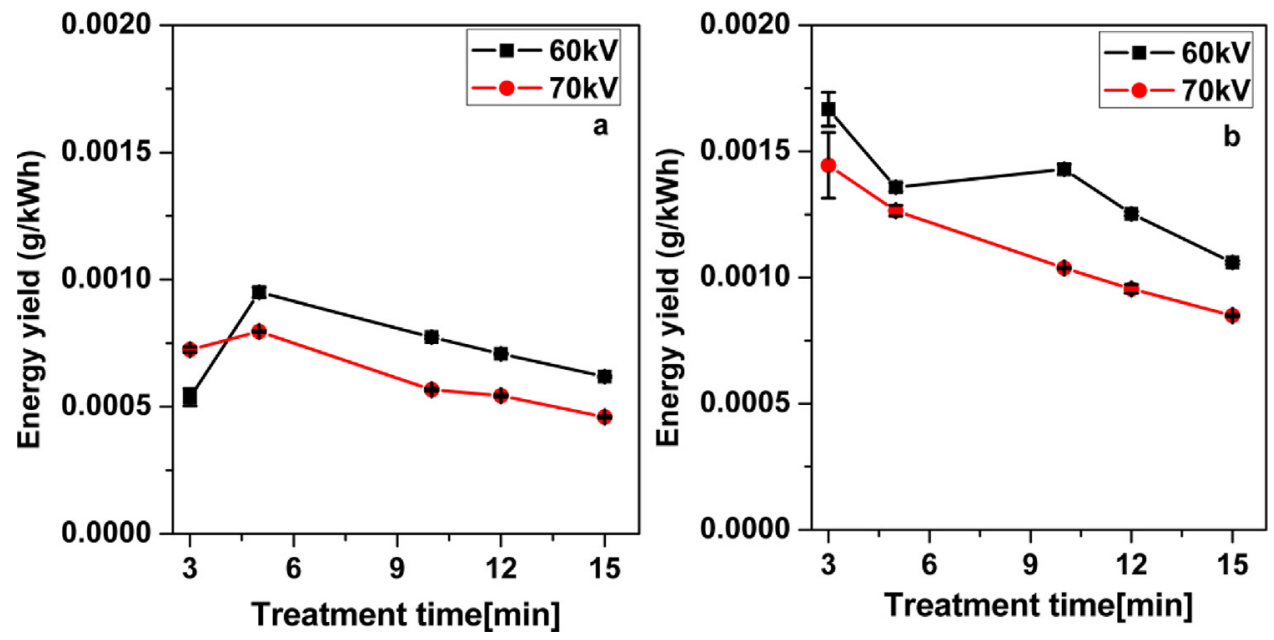

Fig. 4. Evolution of energy yield of humic acid removal at initial concentrations (a) $100 \mathrm{mg} / \mathrm{L}$ and (b) $200 \mathrm{mg} / \mathrm{L}$ under different applied voltages. 

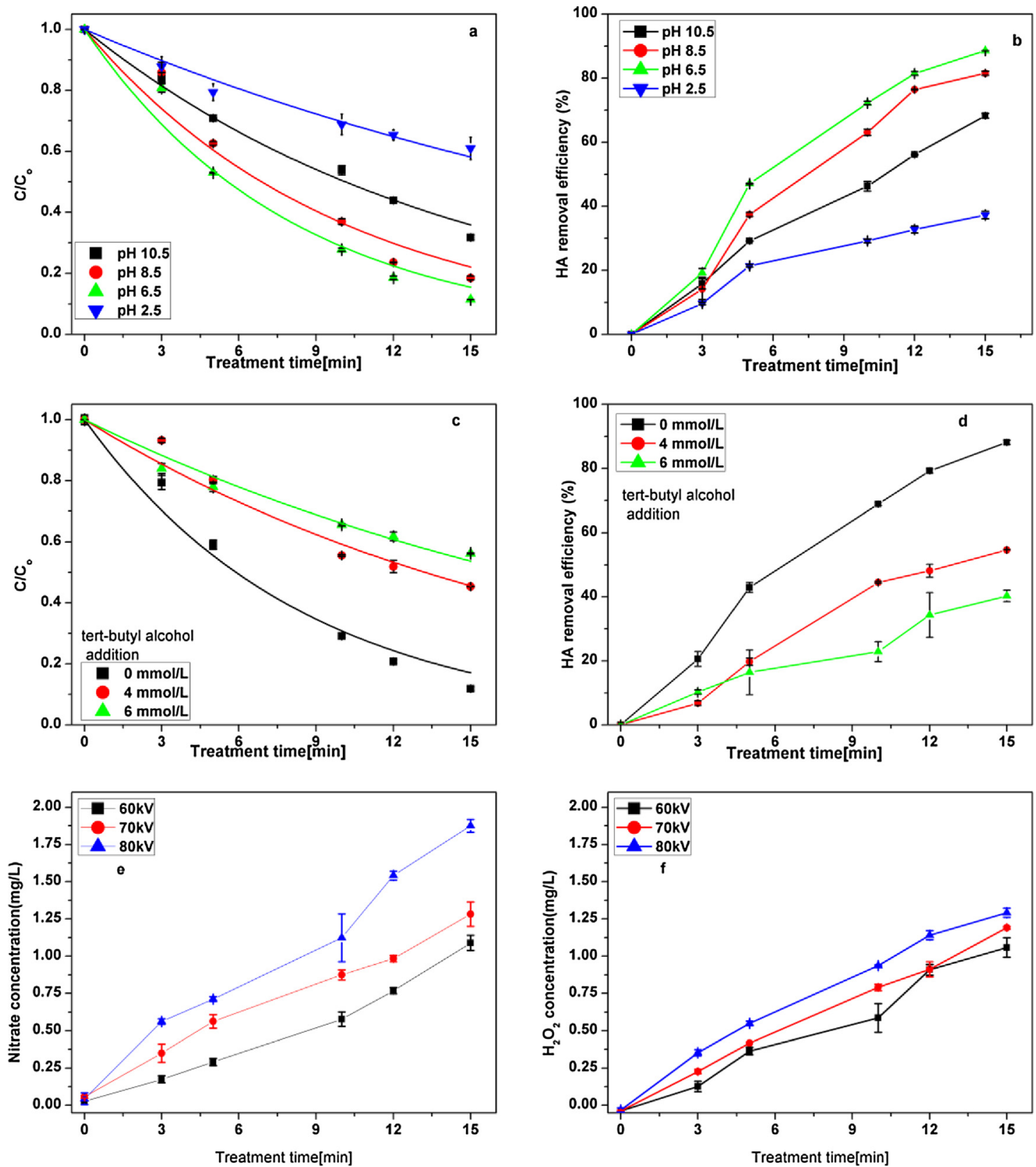

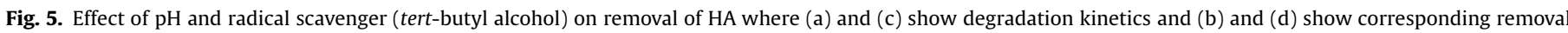

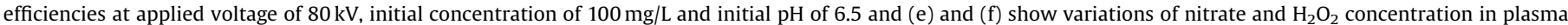
treated HA.

removal efficiencies due to the lower $\mathrm{pH}$. At high $\mathrm{pH}$ indirect oxidation via $\mathrm{O}_{3}$ and $\mathrm{H}_{2} \mathrm{O}_{2}$ results in the formation of $\mathrm{OH}$ radicals [52]. This likely led to the enhanced removal efficiencies at high $\mathrm{pH}$ values of 6.5 and 8.5 . This is due to the fact that the oxidation potential of the $\mathrm{OH}(2.80 \mathrm{~V})$ radical is significantly higher than that of $\mathrm{O}_{3}(2.08 \mathrm{~V})$. The hydroxyl radical reaction contributes more to the change in $\mathrm{pH}$ (to certain extent $\mathrm{pH}<8$ ), which results in an increase in removal efficiency. A similar phenomenon was observed in reports by Huang et al. [56] for the degradation of methylene blue by atmospheric DBD plasma. Superior phenol removal efficiency was achieved at $\mathrm{pH} 10.2$ using a gas-liquid phase pulsed discharge plasma reactor [57]. Sun et al. [58] also reported that the formation of reactive species are $\mathrm{pH}$ dependent. However, an increase in $\mathrm{pH}$ to 10.5 resulted in lower removal efficiencies due to the fact that ${ }^{\circ} \mathrm{OH}$ radicals are consumed by ${ }^{\bullet} \mathrm{OH}^{-}$ ions $[59,60]$. The formation of $\mathrm{HO}_{2}{ }^{-}$in alkaline conditions can consume ${ }^{\bullet} \mathrm{OH}$ radicals and decrease removal efficiency $[61,62]$. The role of carbonate and bicarbonate anions present in HAs in alkali solutions should also be considered, as these ions play an important role in the degradation process, principally acting as radical scavengers [63]. During plasma oxidation, especially at high $\mathrm{pH}$, these anions remain in alkali systems in the form of carbonate and bicarbonate anions, even after oxidation of organic carbon to $\mathrm{CO}_{2}$. Therefore, this leads to decreases in the removal efficiency of humic acid at high $\mathrm{pH}$.

\section{Role of active species}

Active species such as ${ }^{\bullet} \mathrm{OH}$ radicals clearly play a key role in the degradation process. In order to evaluate the effect of ${ }^{\bullet} \mathrm{OH}$, a radical 
scavenger (tert-butyl alcohol) was used. For this study the solution $\mathrm{pH}$ was maintained at 6.5 for a concentration of $100 \mathrm{mg} / \mathrm{L}$ and applied voltage of $80 \mathrm{kV}$. From Fig. 5(c) and (d), it is evident that the radical scavenger has a significant effect on the removal efficiencies. The presence of the scavenger at concentrations of 4 and $6 \mathrm{mmol} / \mathrm{L}$ decreased the overall removal efficiencies by $38 \%$ and
$54 \%$, respectively. This points to the role of hydroxylated reactions in the degradation process for atmospheric plasma treatment. Thus, $\mathrm{O}_{3}, \mathrm{H}_{2} \mathrm{O}_{2}$ and other reactive nitrogen species may have important roles in the degradation of humic acids in the presence of radical scavengers. Similar results were also reported by Hu et al. [64] for the degradation of organophosphate pesticide in

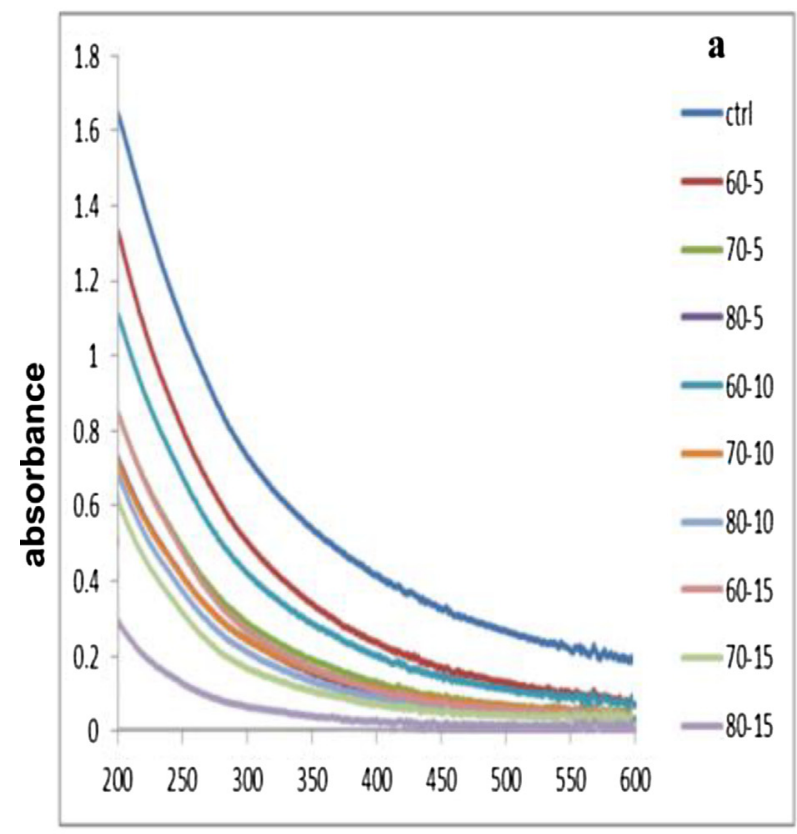

Wavelength[nm]

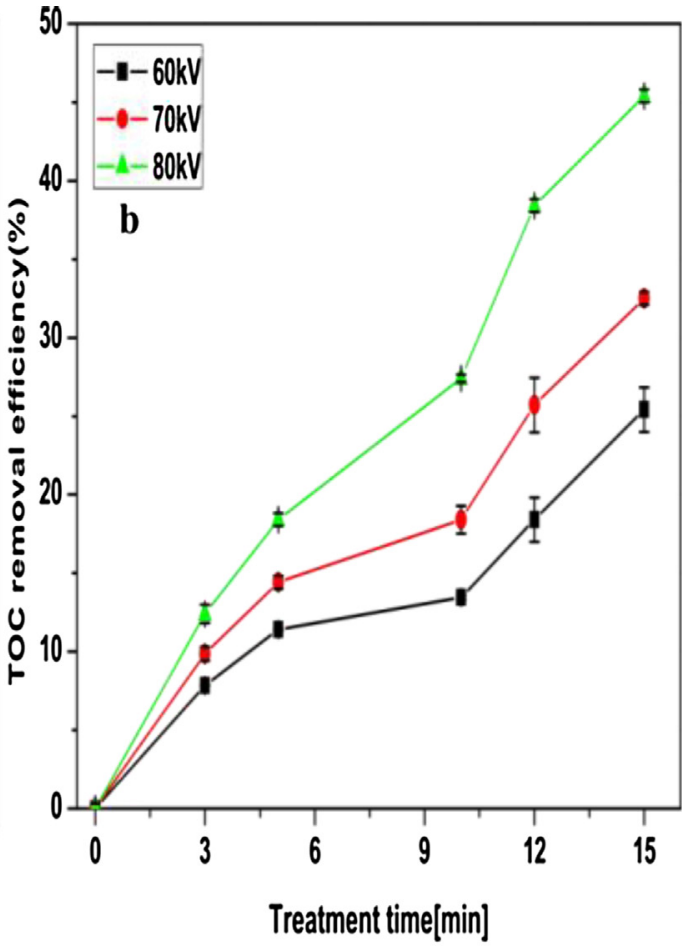

Treatment time[min]

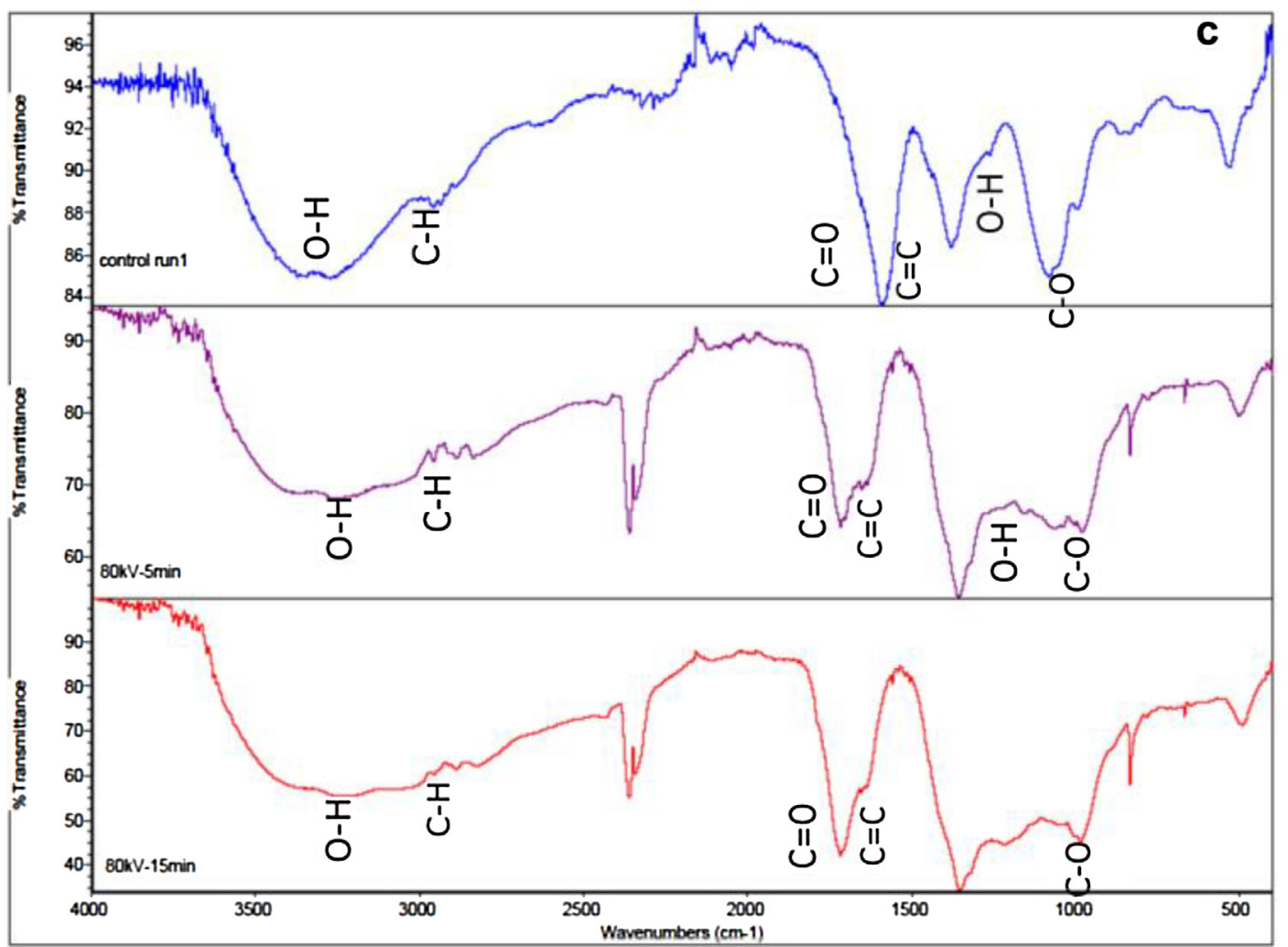

Fig. 6. (a) UV-vis spectrum of HA at various plasma exposure, (b) TOC removal efficiencies of HA after plasma treatment, (c) FTIR spectra of HA samples at different plasma exposure. Note: Figure captions ctrl stands for control and value on the right denotes voltage and right denotes treatment time. 
wastewater by DBD plasma. Li et al. [65] observed a decrease of $43 \%$ and $72 \%$ when 5 and $15 \mathrm{mmol} / \mathrm{L}$ of tert-butanol was added to a 2,4DCP solution during wastewater treatment with a dielectric barrier discharge (DBD) reactor coupled with $\mathrm{TiO} 2$ photocatalysis.

As discussed previously, the $\mathrm{pH}$ of the solution gradually decreased with plasma treatment and the impact of ${ }^{\bullet} \mathrm{OH}$ radical generation by ozone decomposition is reduced. Previous studies by our group revealed the presence of ${ }^{\bullet} \mathrm{OH}$ in the open air plasma discharge using optical emission spectroscopy [66]. On the one hand, many researchers have reported the formation of ${ }^{\circ} \mathrm{OH}$ radicals via chain reactions involving ozone decomposition by UV photons and generation ${ }^{\bullet} \mathrm{O}$ radicals, and then ${ }^{\bullet} \mathrm{OH}$ radicals or $\mathrm{H}_{2} \mathrm{O}_{2}$ decomposition directly to ${ }^{\bullet} \mathrm{OH}[49,50,60]$. It also established that atmospheric air DBD plasma reactors are a good source of both reactive nitrogen and oxygen species [67,68]. To further confirm the presence of these species, the concentration of nitrates, nitrites and $\mathrm{H}_{2} \mathrm{O}_{2}$ was investigated before and after plasma treatment. The concentration of nitrate after $15 \mathrm{~min}$ plasma treatment was found to be $1.05,1.19$ and $1.29 \mathrm{mM}$ for applied voltages of 60,70 , and $80 \mathrm{kV}$ respectively (Fig. 5(e) and (f)). Similar formations of high nitrate concentrations in solutions were reported for gliding arc plasma treatments $[69,70]$. Such increases in nitrates cause a drop in $\mathrm{pH}$. In this study no nitrites were detected, this is due to fact that nitrite is not stable in acidic conditions and can be easily converted to $\mathrm{HNO}_{2}$. The resulting $\mathrm{HNO}_{2}$ is further susceptible to decomposition [70,71]. Nitrates formed under acidic conditions undergo several reactions to form peroxynitrite acid [72]. Lukes et al. [73] reported that the oxidative ability of reactive nitrogen species is lower than reactive oxygen species as they are formed by consuming the stronger oxidant $\cdot \mathrm{OH}$ which in turn converts to $\mathrm{HNO}_{3}$.

Plasma discharges to water also generates $\mathrm{H}_{2} \mathrm{O}_{2}$ [72,74]. The concentrations of $\mathrm{H}_{2} \mathrm{O}_{2}$ increased linearly with respect to treatment time for all voltages with concentrations in the range of 0.174-1.87 mM. The high amounts of $\mathrm{H}_{2} \mathrm{O}_{2}$ in the treated effluent are due to the retention of reactive species in the gas phase in contact with the treated liquid for extended periods of time. Earlier work by our group achieved stable concentrations of $\mathrm{H}_{2} \mathrm{O}_{2}$ in solutions for extended storage times of several weeks in a closed reactor [35].

\section{Mineralization of humic acid}

Mineralization of humic acid after atmospheric plasma treatment was evaluated via changes in the UV-vis spectra, TOC values and FTIR. The evolution of UV-vis absorbance spectra with increases in time and applied voltage are presented in Fig. 6(a). It can be observed that the absorbance of the UV-vis spectra was gradually decreased with increasing treatment time and voltage. These results correlate with the degradation values of humic acid described earlier. Similar results in UV-vis absorbance values were reported by Wang et al. [31] for DBD plasma treatment of humic acid. Ozonation also shows significant reductions in absorbance values [63]. The TOC values after plasma treatment are presented in Fig. 6(b). The TOC values tend to decrease with increases in plasma treatment. The TOC removal efficiencies achieved were $25 \%, 33 \%$ and $45 \%$ for $60 \mathrm{kV}, 70 \mathrm{kV}$ and $80 \mathrm{kV}$ respectively, after $15 \mathrm{~min}$. In comparison with the HA removal efficiencies, the TOC removal efficiencies achieved were not more than $50 \%$, which can be attributed to the formation of low-molecular weight compounds such as carboxylic acids before being completely mineralized [75].

FTIR analysis was performed in order to confirm the structural changes in humic acid after plasma treatment. Fig. 6(c) shows the FTIR spectrum of plasma treated humic acid. Typical broad and intense bands are centred around $3400 \mathrm{~cm}^{-1}$, which is attributed to the associated $\mathrm{O}-\mathrm{H}$ stretching vibrations (alcohols, phenols and carboxylic acids). The bands at $\sim 2924$ and $2854 \mathrm{~cm}^{-1}$ could be assigned to aliphatic $\mathrm{C}-\mathrm{H}$ stretching, the band at $1720 \mathrm{~cm}^{-1}$ (due to the $\mathrm{C}=\mathrm{O}$ stretching vibration) and the band at $1405 \mathrm{~cm}^{-1}$ (attributed to the $\mathrm{O}-\mathrm{H}$ bend in the $\mathrm{COOH}$ group) [76]. The band at $1630-1600 \mathrm{~cm}^{-1}$ could be assigned to aromatic $C=C$ stretching. The band at $\sim 1382 \mathrm{~cm}^{-1}$ is attributed to $\mathrm{O}-\mathrm{H}$ deformation or $\mathrm{C}-\mathrm{O}$ stretching or $\mathrm{C}-\mathrm{H}$. The broad band at $1220 \mathrm{~cm}^{-1}$ corresponds to oxygentated groups of aromatic ethers, phenols and carboxylic acids [77]. A few changes were observed in the IR spectra of the plasma treated samples. When compared to the control samples the peak at $3447 \mathrm{~cm}^{-1}$ strengthened, denoting $\mathrm{O}-\mathrm{H}$ vibration of carboxylic and alcoholic groups. The presence of weak bands at $\sim 2924$ and $2854 \mathrm{~cm}^{-1}$ indicates changes in aliphatic $\mathrm{C}-\mathrm{H}$ stretching, which increased with plasma treatment time. The trend of band increasing at $1730 \mathrm{~cm}^{-1}$ with treatment time indicates plasma oxidation of $\mathrm{C}=\mathrm{C}$ bonds, producing $\mathrm{C}=\mathrm{O}$. This is attributed to the production of saturated aldehyde, carboxylic acids or other secondary oxidation products [63]. Similarly, a decrease in the peak at $1630 \mathrm{~cm}^{-1}$ would indicate the reduction in aromaticity of humic acid. Interestingly, a new band around $1382 \mathrm{~cm}^{-1}$ was observed across all the plasma treated samples, which was not observed for the control. This peak corresponds to the formation of nitrate during air plasma treatment. A similar peak was also observed for ozonated humic acid samples [78], with the authors reporting that the presence of reactive nitrogen species might be responsible for such changes in the humic acid. Thus, plasma treatment changes the structure of humic acid which results in a decrease in armoticity and an increase in carboxylic acidity [78]. Most of the literature supports these findings, that plasma oxidizes the humic substances into lower molecular weight compounds [79]. This plasma oxidized organic matter can be more aliphatic in character and more polar similar to ozonation and is expected to be recalcitrant to further oxidation.

\section{THM degradation study and DBP reduction potential}

It can be observed from Fig. 7. that the four THMs, namely $\mathrm{CHCL}_{3}, \mathrm{BDCM}, \mathrm{DBCM}$ and $\mathrm{BF}$ were identified at retention times of $1.25,1.96,3.48$ and $6.82 \mathrm{~min}$, respectively. The removal efficiencies of THMs by atmospheric air plasma is presented in Fig. 8. The removal efficiencies achieved after $80 \mathrm{kV}$ and $30 \mathrm{~min}$ of plasma treatment were found to be $99 \%$ for chloroform, $94 \%$ for BDCM, $89 \%$ for DBCM and $74 \%$ for BF, respectively. As observed with $\mathrm{HA}$, a further increase in the initial concentration reduced the overall removal efficiency. Among the four THMs, $\mathrm{CHCL}_{3}$ was the most susceptible to degradation. In addition, degradation of THMs especially for BF, at the start of plasma treatment was relatively faster and decreased as plasma treatment continued. This phenomenon may be due to the fact that bromine substituents are better leaving groups than chlorine substituents. Moreover, the reactive species generated preferentially break $\mathrm{C}-\mathrm{Br}$ bonds $(\sim 55.5 \mathrm{kcal} / \mathrm{mol})$ over $\mathrm{C}-\mathrm{Cl}$ bonds $(66-100 \mathrm{kcal} / \mathrm{mol})$ in a mixed halogenated compound during the dehalogenation process [80]. These results are also evident in the observed rate constant values. From Table 1 it can be observed that THMs removal also followed a first-order kinetic model. It was also observed that after plasma treatment of $30 \mathrm{~min}$, due to a sufficient decrease in BF concentration, the reaction pathways of BDCM and DBCM was able to compete and faster kinetics were observed. This phenomenon can also be observed from Fig. 8. which shows the slightly higher peaks for $\mathrm{DBCM}$, and $\mathrm{BDCM}$ in comparison with $\mathrm{CHCL}_{3}$ and $\mathrm{BF}$. Interestingly, the overall removal efficiencies achieved was found to be greatest for $\mathrm{CHCL}_{3}$ and least for $\mathrm{BF}$. This is attributed to the volatility of THMs [81], where $\mathrm{CHCL}_{3}$ with vapour pressure of $26.3 \mathrm{kPa}$ could more easily escape and react with the gaseous 

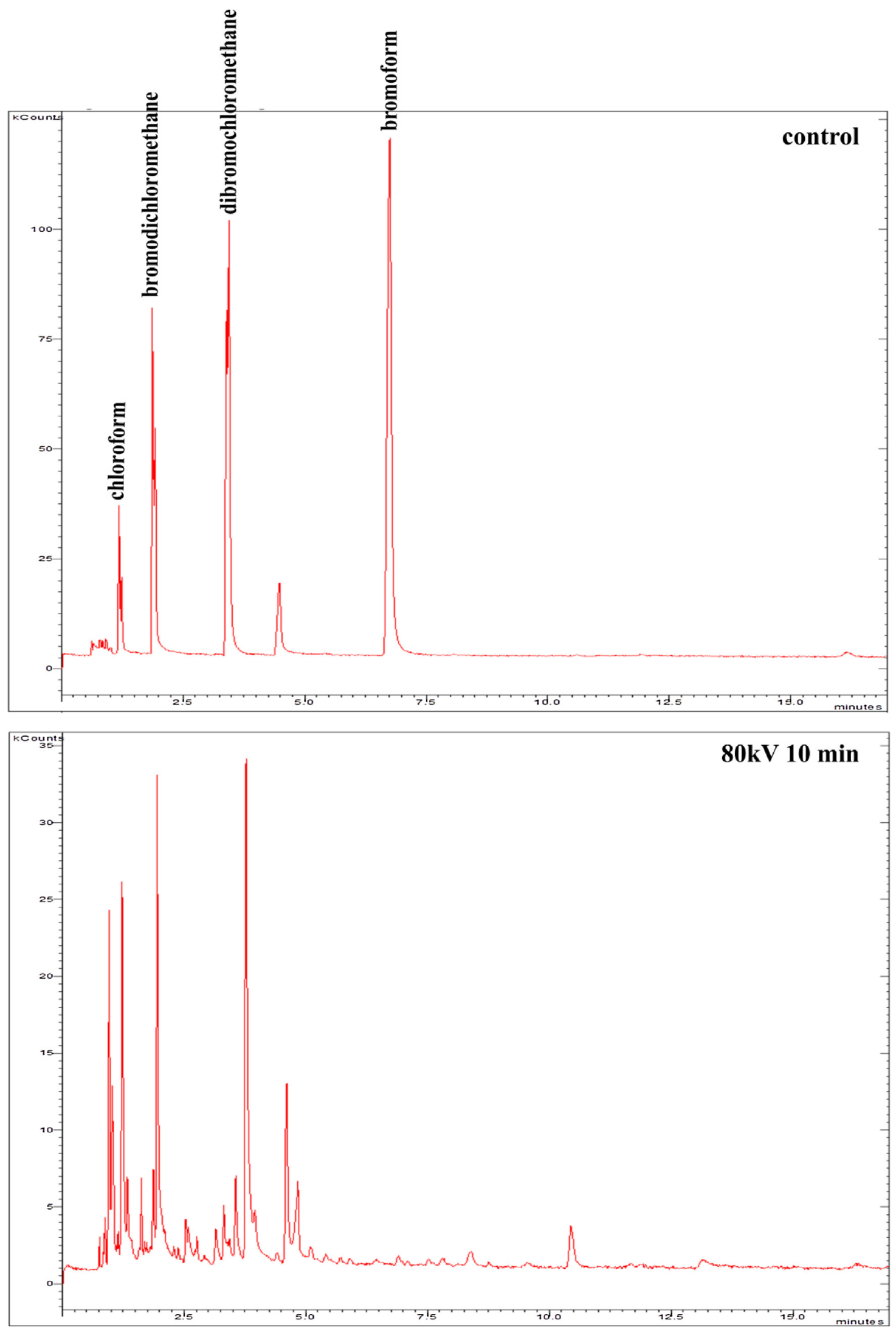

Fig. 7. GC-MS chromatogram of THMs control and plasma treated THM at $80 \mathrm{kV}$ for $10 \mathrm{~min}$ THM.

Please cite this article in press as: C. Sarangapani, et al., Humic acid and trihalomethane breakdown with potential by-product formations for atmospheric air plasma water treatment, J. Ind. Eng. Chem. (2017), https://doi.org/10.1016/j.jiec.2017.10.042 
reactive species than $\mathrm{BF}$ at a vapour pressure of $0.6 \mathrm{kPa}$. Furthermore, the reaction of plasma active species with the sample also depends upon the hydrophobicity. Increases in the hydrophobicity of a solution would make it more efficient as a radical scavenger. Among the THMs studied BF is the most hydrophobic. It can be concluded that compounds less hydrophobic and more volatile are more susceptible to degradation [82]. The plasma removal efficiencies in the present study follows $\mathrm{CHCL}_{3}$ $>\mathrm{BDCM}>\mathrm{DBCM}>\mathrm{BF}$. Similar observations were reported by Bayona Termens et al. [30] and Shemer and Narkis [83].

The efficacy of atmospheric plasma for the degradation of DBPs after chlorination in HA acid samples was also evaluated. For this purpose, sodium hypochlorite was added to each of the plasma treated HA samples (at $80 \mathrm{kV}$ for treatment durations of 0,10 , $15 \mathrm{~min}$ ) and incubated for one week. After incubation, the samples were tested for the formation of DBPs. GC-MS analysis revealed that $\mathrm{CHCL}_{3}$ was the only DBP detected. It was observed that the concentration of $\mathrm{CHCL}_{3}$ detected in the $\mathrm{HA}$ samples was found to decrease with plasma treatment. The concentration of $\mathrm{CHCL}_{3}$ detected was found to be $98 \mu \mathrm{g} / \mathrm{L}$ in the control, $68 \mu \mathrm{g} / \mathrm{L}$ for $10 \mathrm{~min}$ and $33 \mu \mathrm{g} / \mathrm{L}$ for $15 \mathrm{~min}$ plasma treatment, respectively. Similar reductions in DBPs formation potential was achieved in ozone-UV treatment of river water by Chin and Be'rube' [84]. However, Wang et al. [31] reported an increase in the levels of $\mathrm{CHCL}_{3}$ for $\mathrm{HA}$ sample
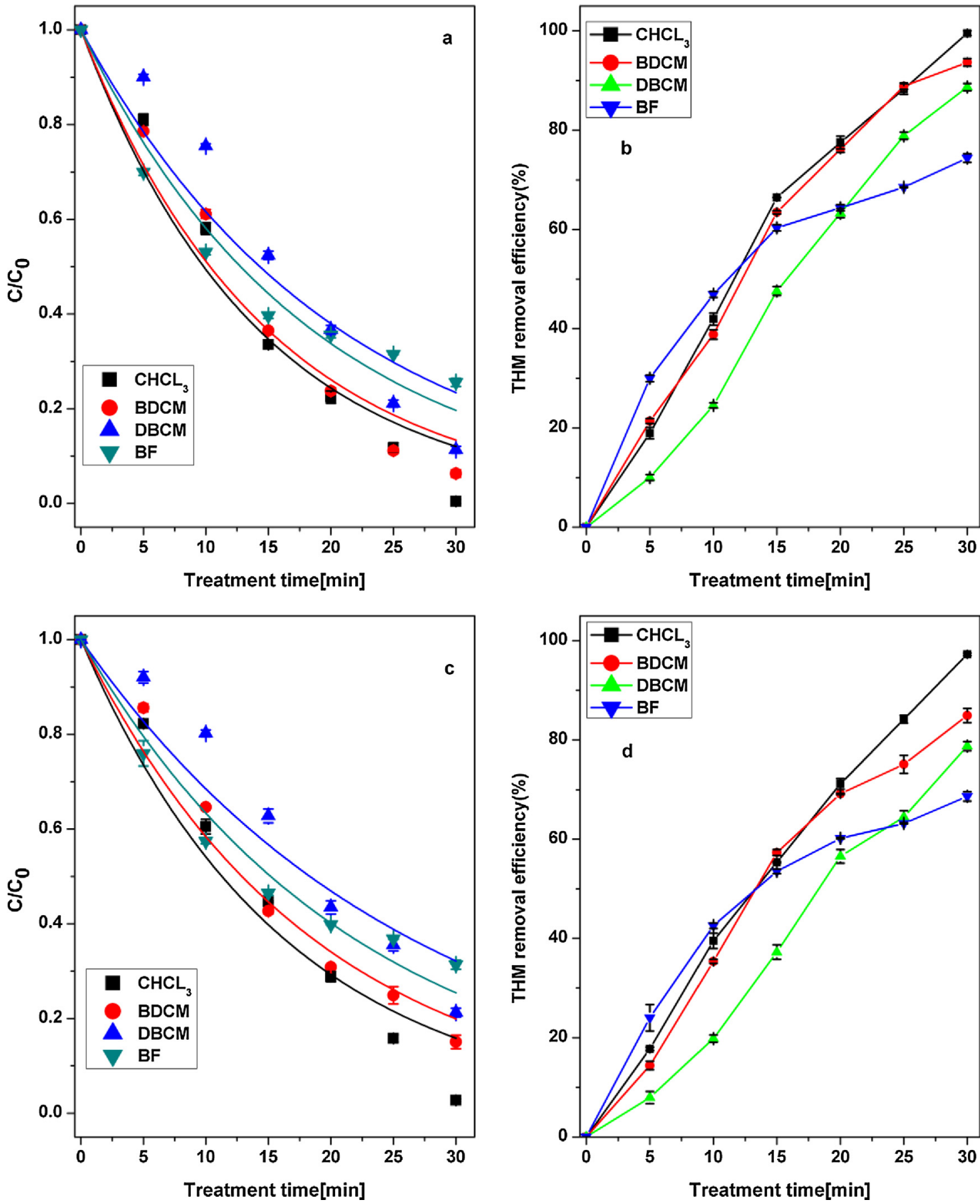

Fig. 8. Degradation kinetics of THMs removal at initial concentration of (a) $10 \mathrm{mg} / \mathrm{L}$ and (c) $20 \mathrm{mg} / \mathrm{L}$ where (b) and (d) show corresponding removal efficiencies. 
exposed to 20 min plasma discharge, while further increases in treatment time reduced the $\mathrm{CHCL}_{3}$ levels. Nan et al. [22] reported that ozonation enhanced the yields of all detected chlorine DBPs except $\mathrm{CHCL}_{3}$. Verma et al. [85] also reported increased amounts of DBP's after ozonation. It should be noted that the increase in DBPs potential depends on the presence of precursor ions such as $\mathrm{Br}^{-}$. Ozone can oxidize bromide present in water to bromate which upon further oxidation leads to production of hypobromous acid and hypobromate [86]. This further can react with organic matter present in water to form brominated disinfection by-products. In this work, no such production of Bromate ions was observed. Therefore, the reduction in DBP's potential can be attributed to oxidation of organic matter by direct and indirect mechanism by plasma active species. However, it is known that plasma treatment may not completely mineralize the organic matter of HA but it can alter the chemical structure of some of the DBP precursors that do not react with chlorine to form chloroform. It is known from previous studies that ozonation reduced the formation of THMs when compared to chorination [87]. Verma et al. [85] reported that the occurrence of THMs was $61 \%$ less compared to chlorination. In the present work, the decrease in THMs formation was $60 \%$. Hence, atmospheric cold plasma treatment can be used as a disinfectant alternative as it can reduce the formation of one of the most prevalent human carcinogenic DBPs.

\section{Conclusion}

The degradation of humic acid using atmospheric plasma was investigated. The maximum removal efficiencies found were $93 \%$ at $80 \mathrm{kV}$ for $15 \mathrm{~min}$ of plasma treatment. Degradation of humic acids by plasma treatment follows an overall first-order kinetic model and the removal efficiencies are dependent on applied voltage, treatment time, initial $\mathrm{pH}$ and initial concentration. The role of plasma active species such as ${ }^{\bullet} \mathrm{OH}$ radical, nitrates and $\mathrm{H}_{2} \mathrm{O}_{2}$ in the degradation process was investigated. The decrease in UVvis absorbance and TOC at extended treatment times suggests that plasma treatment mineralized the humic acid. A decrease in aromaticity and an increase in carboxylic acidity following plasma treatment of humic substances and plasma induced changes in functional groups were monitored by FTIR. Furthermore, plasma treatment also degraded trihalomethanes in water and reduced the potential for formation of DBPs. The removal efficiencies followed; $\mathrm{CHCL}_{3}>\mathrm{BDCM}>\mathrm{DBCM}>\mathrm{BF}$. The kinetic values obtained from this study can be used to predict the removal of DBP precursors for water with similar characteristics as the one used in this study. This demonstrates the potential of plasma treatment for reducing HAs, THMs and other DBPs in water. Further studies could focus on the formation of other halo acids post plasma treatment.

\section{Acknowledgements}

The authors would like to acknowledge funding from the Food Institutional Research Measure administered by the Department of Agriculture, Food \& the Marine, Ireland (Grant number: 13F442), and this publication has emanated from research supported in part by Science Foundation Ireland (SFI) under the Grant Numbers 14/ IA/2626, SFI/16/BBSRC/3391 and the BBSRC under the Grant Reference BB/P008496/1.

\section{References}

[1] M.A. Alsheyab, A.H. Muñoz, Desalination 207 (2007) 179

[2] J. Lee, D. Lee, J. Sohn, Water Sci. Technol. 55 (2007) 307.

[3] A. Moncayo-Lasso, C. Pulgarin, N. Benítez, Water Res. 42 (2008) 4125

[4] R. Mosteo, N. Miguel, S. Martin-Muniesa, M.P. Ormad, J.L. Ovelleiro, J. Hazard. Mater. 172 (2009) 661.
[5] M.R.M. Shafiee, L. Taghavi, Health Effects of Trihalomethanes as Chlorinated Disinfection by Products: A Review Article, vol. 68, World Academy of Science, Engineering and Technology, 2012.

[6] W.D. King, L.D. Marrett, Cancer Causes Control 7 (1996) 596

[7] H. Gallard, U. von Gunten, Water Res. 36 (2002) 65.

[8] K. Waller, S.H. Swan, G. DeLorenze, B. Hopkins, Epidemiology 9 (1998) 134.

[9] S.H. Swan, K. Waller, B. Hopkins, G. Windham, L. Fenster, C. Schaefer, R.R. Neutra, Epidemiology 9 (1998) 126.

[10] S.D. Richardson, TrAC Trends Anal. Chem. 22 (2003) 666.

[11] P.C. Singer, A.W.W. Association, Formation and Control of Disinfection Byproducts in Drinking Water, AWWA, 1999.

[12] EPA, Drinking Water Guidance on Disinfection By-Products Advice Note No. 4. Version 2, Enivornmental Protection Agency, 2007.

[13] Y. Wang, Q. Wang, B.-Y. Gao, Q. Yue, Y. Zhao, Chem. Eng. J. 193 (2012) 59.

[14] M.S. Rauthula, V.C. Srivastava, Chem. Eng. J. 168 (2011) 35.

[15] Y. Wu, S. Zhou, F. Qin, Y. Lai, H. Peng, Huan jing ke xue = Huanjing kexue/[bian ji, Zhongguo ke xue yuan huan jing ke xue wei yuan hui Huan jing ke xue bian ji wei yuan hui.] 31 (2010) 996.

[16] S. Qiao, D. Sun, J. Tay, C. Easton, Water Sci. Technol. 47 (2003) 211.

[17] M. Prisciandaro, A. Salladini, D. Barba, Chem. Eng. Trans. Ser. 14 (2008) 437.

[18] H.-J. Fan, T. Chiu, H.-S. Yang, W.-C. Chen, E. Furuya, J. Environ. Eng. Manag. 17 (2007) 325.

[19] Y.-h. Wang, K.-c. Chen, C.-r. Chen, Catal. Today 216 (2013) 261.

[20] M.J. Cuetos, X. Gomez, M. Otero, A. Morán, Biochem. Eng. J. 40 (2008) 99.

[21] H.J. Porwal, A.V. Mane, S.G. Velhal, Water Resour. Ind. 9 (2015) 1.

[22] C. Nan, M. Tingting, L. Kuixiao, Y. Zhang, Y. Min, J. Environ. Sci. 21 (2009) 409.

[23] B. Jiang, J. Zheng, S. Qiu, M. Wu, Q. Zhang, Z. Yan, Q. Xue, Chem. Eng. J. 236 (2014) 348.

[24] C. Sarangapani, Y. Dixit, V. Milosavljevic, P. Bourke, C. Sullivan, P. Cullen, Water Sci. Technol. 75 (2017) 207.

[25] C. Sarangapani, G. O’Toole, P. Cullen, P. Bourke, Innov. Food Sci. Emerg. Technol. (2017) 1466, doi:http://dx.doi.org/10.1016/j.ifset.2017.02.012.

[26] C. Sarangapani, N. Misra, V. Milosavljevic, P. Bourke, F. O’Regan, P. Cullen, J. Water Process Eng. 9 (2016) 225.

[27] Y. Devi, R. Thirumdas, C. Sarangapani, R. Deshmukh, U. Annapure, Food Control 77 (2017) 187.

[28] D. Ziuzina, S. Patil, P. Cullen, K. Keener, P. Bourke, J. Appl. Microbiol. 114 (2013) 778.

[29] R. Thirumdas, C. Sarangapani, U.S. Annapure, Food Biophys. 10 (2015) 1.

[30] Bertran, S. E., Jover, E., Bayona, T. J. M., Erra, S. P., Molina, M. R., Reyes, C. C. (2010). Method for removing trihalomethanes and/or emerging pollutants using plasma, Google Patents.

[31] T. Wang, G. Ou, J. Ren, O. Yan, O. Sun, D. Liang, S. Hu, Water Res. 89 (2016) 28

[32] I. Panorel, I. Kornev, H. Hatakka, S. Preis, Water Sci. Technol. 11 (2011) 238.

[33] Fuhr, J. R., Kelleher, D. E., Martin, W. C., Musgrove, A., Sugar, J., Wiese, W. L. Reader, J. (1999). NIST Atomic Spectra Database. Version 2.0, March 1999, NIST Physical Reference Data.

[34] B. Jiang, J. Zheng, Q. Liu, M. Wu, Chem. Eng. J. 204-206 (2012) 32.

[35] D. Boehm, C. Heslin, P.J. Cullen, P. Bourke, Sci. Rep. 6 (2016).

[36] T. Shao, C. Zhang, K. Long, D. Zhang, J. Wang, P. Yan, Y. Zhou, Appl. Surf. Sci. 256 (2010) 3888 .

[37] S. Tao, L. Kaihua, Z. Cheng, Y. Ping, Z. Shichang, P. Ruzheng, J. Phys. D: Appl. Phys. 41 (2008) 215203.

[38] T. Shao, C. Zhang, Y. Yu, Z. Fang, P. Yan, EPL (Europhys. Lett.) 97 (2012) 55005.

[39] L. Gao, L. Sun, S. Wan, Z. Yu, M. Li, Chem. Eng. J. 228 (2013) 790.

[40] N. Lu, J. Li, X. Wang, T. Wang, Y. Wu, Plasma Chem. Plasma Process. 32 (2012) 109.

[41] P.M.K. Reddy, C. Subrahmanyam, Ind. Eng. Chem. Res. 51 (2012) 11097.

[42] B. Jiang, J. Zheng, Q. Liu, M. Wu, Chem. Eng. J. 204 (2012) 32.

[43] M. Magureanu, D. Piroi, N.B. Mandache, V. David, A. Medvedovici, V.I. Parvulescu, Water Res. 44 (2010) 3445.

[44] P.M.K. Reddy, B.R. Raju, J. Karuppiah, E.L. Reddy, C. Subrahmanyam, Chem. Eng. J. 217 (2013) 41.

[45] H. Selcuk, M. Bekbolet, Chemosphere 73 (2008) 854.

[46] J.K. Edzwald, W.C. Becker, K.L. Wattier, Am. Water Works Assoc. (1985) 122.

[47] A. Kerc, M. Bekbolet, A.M. Saatci, Int. J. Photoenergy 5 (2003) 75.

[48] G.V. Korshin, C.-W. Li, M.M. Benjamin, Water Res. 31 (1997) 1787.

[49] P. Bruggeman, J. Degroote, C. Leys, J. Vierendeels, Plasma characteristics in air and vapor bubbles in water, Proceedings of 28th International Conference on Phenomena in Ionized Gases (15-20 July 2007, Prague, Czech Republic), Institute of Plasma Physics AS CR Prague, 2007, pp. 859.

[50] P. Bruggeman, L. Graham, J. Degroote, J. Vierendeels, C. Leys, J. Phys. D: Appl. Phys. 40 (2007) 4779.

[51] D. Willberg, P. Lang, R. Höchemer, A. Kratel, M. Hoffmann, Environ. Sci. Technol. 30 (1996) 2526.

[52] P. Lukes, A.T. Appleton, B.R. Locke, IEEE Trans. Ind. Appl. 40 (2004) 60.

[53] Z.-Z. Su, K. Ito, K. Takashima, S. Katsura, K. Onda, A. Mizuno, J. Phys. D: Appl. Phys. 35 (2002) 3192.

[54] L. Grabowski, E. Van Veldhuizen, A. Pemen, W. Rutgers, Plasma Sources Sci. Technol. 16 (2007) 226.

[55] A. Lopez, H. Benbelkacem, J.S. Pic, H. Debellefontaine, Environ. Technol. 25 (2004) 311.

[56] F. Huang, L. Chen, H. Wang, Z. Yan, Chem. Eng. J. 162 (2010) 250

[57] J. Li, M. Sato, T. Ohshima, Thin Solid Films 515 (2007) 4283.

[58] B. Sun, M. Sato, J.S. Clements, J. Electrostat. 39 (1997) 189.

[59] S. Mededovic, B.R. Locke, Ind. Eng. Chem. Res. 46 (2007) 2702. 
[60] P. Attri, Y.H. Kim, D.H. Park, J.H. Park, Y.J. Hong, H.S. Uhm, K.-N. Kim, A. Fridman, E.H. Choi, Sci. Rep. 5 (2015) 9332.

[61] M. Tahara, M. Okubo, Proc. 2012 Joint Electrostatics Conference, Detection of Free Radicals Produced by a Pulsed Streamer Corona Discharge in Solution Using Electron Spin Resonance, vol. 102017.

[62] M. Muruganandham, M. Swaminathan, Dyes Pigments 62 (2004) 269.

[63] H. Miao, W. Tao, J. Chem. Technol. Biotechnol. 83 (2008) 336.

[64] Y. Hu, Y. Bai, H. Yu, C. Zhang, J. Chen, Bull. Environ. Contam. Toxicol. 91 (2013) 314.

[65] S. Li, X. Ma, L. Liu, X. Cao, RSC Adv. 5 (2015) 1902.

[66] C. Sarangapani, M. Danaher, B. Tiwari, P. Lu, P. Bourke, P. Cullen, Chem. Eng. J. 326 (2017) 700.

[67] N. Misra, S. Pankaj, T. Walsh, F. O’Regan, P. Bourke, P. Cullen, J. Hazard. Mater. 271 (2014) 33.

[68] P.J. Cullen, N. Misra, L. Han, P. Bourke, K. Keener, C. O’Donnell, T. Moiseev, J.P. Mosnier, V. Milosavljević, IEEE Trans. Plasma Sci. 42 (2014) 2368.

[69] J.-L. Brisset, E. Hnatiuc, Plasma Chem. Plasma Process. 32 (2012) 655.

[70] P. Lu, D. Boehm, P. Bourke, P.J. Cullen, Plasma Process. Polym. 14 (August (8)) (2017).

[71] J.-L. Brisset, J. Pawlat, Plasma Chem. Plasma Process. 36 (2016) 355.

[72] J.-L. Brisset, B. Benstaali, D. Moussa, J. Fanmoe, E. Njoyim-Tamungang, Plasma Sources Sci. Technol. 20 (2011) 034021.
[73] P. Lukes, E. Dolezalova, I. Sisrova, M. Clupek, Plasma Sources Sci. Technol. 23 (2014) 015019.

[74] J. Staehelin, J. Hoigne, Environ. Sci. Technol. 16 (1982) 676.

[75] K.-S. Kim, S.K. Kam, Y.S. Mok, Chem. Eng. J. 271 (2015) 31.

[76] D.G. Lumsdon, A.R. Fraser, Environ. Sci. Technol. 39 (2005) 6624.

[77] X. Qin, F. Liu, G. Wang, G. Huang, Environ. Earth Sci. 73 (2015) 4011.

[78] F.J. Rodríguez, P. Schlenger, M. García-Valverde, Sci. Total Environ. 541 (2016) 623.

[79] P.M.K. Reddy, S. Mahammadunnisa, C. Subrahmanyam, Chem. Eng. J. 238 (2014) 157.

[80] W.Z. Tang, S. Tassos, Water Res. 31 (1997) 1117.

[81] H. Okuno, B. Yim, Y. Mizukoshi, Y. Nagata, Y. Maeda, Ultrason. Sonochem. 7 (2000) 261.

[82] Y.G. Adewuyi, Ind. Eng. Chem. Res. 40 (2001) 4681.

[83] H. Shemer, N. Narkis, Isr. J. Chem. 46 (2006) 27.

[84] A. Chin, P. Bérubé, Water Res. 39 (2005) 2136.

[85] K. Verma, D. Gupta, A. Gupta, J. Environ. Chem. Eng. 4 (2016) 3021.

[86] J. Patoczka, P. Tyrrell, M. Wynne, Proc. Water Environ. Fed. 2011 (2011) 189.

[87] R. Vranitzky, J. Lahnsteiner, A. Jaques, Sewage Sludge Disintegration Using Ozone-A Method of Enhancing the Anaerobic Stabilization of Sewage Sludge, Va Tech Wabah, R\&D Process Engineering, Siemensstrasse, 2005, pp. 89. 